\title{
Vibrio porteresiae sp. nov., a diazotrophic bacterium isolated from a mangrove-associated wild rice (Porteresia coarctata Tateoka)
}

Correspondence

Sudha Nair

microbiology@mssrf.res.in

\author{
N. Rameshkumar, ${ }^{1}$ Youhei Fukui, ${ }^{2}$ Tomoo Sawabe ${ }^{2}$ and Sudha Nair ${ }^{1}$ \\ ${ }^{1}$ Microbiology Department, M. S. Swaminathan Research Foundation, 3rd Cross Street, Taramani \\ Institutional Area, Chennai - 600 113, India \\ ${ }^{2}$ Laboratory of Microbiology, Faculty of Fisheries Sciences, Hokkaido University, 3-1-1 Minato-cho, \\ Hakodate 041-8611, Japan
}

The genus Vibrio encompasses a genetically diverse group of heterotrophic marine bacteria that are commonly found in aquatic habitats and in association with marine organisms (Thompson et al., 2004a). Members of the genus Vibrio may account for nearly $10 \%$ of the culturable

Abbreviation: NfM, nitrogen-free medium.

The GenBank/EMBL/DDBJ accession numbers for the 16S rRNA gene sequences of strains MSSRF30 ${ }^{\top}$ and MSSRF31 are EF488079 and EF488080, respectively. The accession numbers for the $\operatorname{rec} A, p y r H$, rpoA and nifH gene sequences of strains MSSRF $30^{\top}$ and MSSRF3 1 are EF547199, EF554361, EF547200, EF554362 and EU072027EU072030, inclusive.

Three supplementary neighbour-joining phylogenetic trees based on partial $r p o A, r e c A$ and $p y r H$ gene sequences and the results of PCR genomic fingerprinting analyses are available as Supplementary Figures S1-S4 with the online version of this paper. A supplementary table detailing the amplification and sequencing primers used in this study is also available. marine bacteria (Thompson et al., 2004b). They include several species that are pathogenic for humans and marine animals and some that are facultative symbiotic (Thompson et al., 2004a). To date, relatively few studies have demonstrated that vibrios are capable of $\mathrm{N}_{2}$-fixation; this characteristic has so far been confirmed for Vibrio diazotrophicus (Guerinot et al., 1982), Vibrio natriegens, Vibrio pelagius and Vibrio cincinnatiensis (Urdaci et al., 1988), Vibrio anguillarum and Vibrio campbellii (Holguin et al., 1992).

During a study of diazotrophic bacteria from mangroveassociated wild rice, numerous isolates that could fix atmospheric nitrogen were isolated. Based on the preliminary characterization, these isolates were tentatively identified as members of the genera Swaminathania, Vibrio and Serratia. In the present work, we describe the isolation and taxonomic characterization of two novel 
diazotrophs (strains MSSRF30 ${ }^{\mathrm{T}}$ and MSSRF31) belonging to the genus Vibrio.

Strains MSSRF30 ${ }^{\mathrm{T}}$ and MSSRF31 were isolated from a wild rice collected from Pichavaram mangroves, India. The plant roots were washed with sterilized distilled water, surface-sterilized with sodium hypochlorite $(4 \%)$ for $5 \mathrm{~min}$ and then washed several times using sterile distilled water. The surface-sterilized root samples were macerated in a blender, serially diluted and $100 \mu \mathrm{l}$ aliquots were inoculated into $30 \mathrm{ml}$ test tubes containing $10 \mathrm{ml}$ of semisolid N-free medium (NfM) (Gyaneshwar et al., 2001) consisting of $\left(\mathrm{l}^{-1}\right): 5 \mathrm{~g}$ sucrose; $3 \mathrm{~g}$ mannitol; $0.8 \mathrm{~g}$ $\mathrm{K}_{2} \mathrm{HPO}_{4} ; 0.2 \mathrm{~g} \mathrm{KH}_{2} \mathrm{PO}_{4} ; 0.2 \mathrm{~g} \mathrm{MgSO}_{4} .7 \mathrm{H}_{2} \mathrm{O} ; 20 \mathrm{~g} \mathrm{NaCl}$; $0.02 \mathrm{~g} \mathrm{CaCl}_{2} ; 28 \mathrm{mg} \mathrm{Na} 2 \mathrm{FeEDTA} ; 25 \mathrm{mg} \mathrm{Na} \mathrm{MoO}_{4} .2 \mathrm{H}_{2} \mathrm{O}$; $2 \mathrm{ml} 0.5 \%$ bromothymol blue in $0.2 \mathrm{~N} \mathrm{KOH}$ and $2 \mathrm{~g}$ agar. The final $\mathrm{pH}$ was adjusted to 7.0 by KOH. The NfM was modified by adding $0.02 \mathrm{~g}$ yeast extract $(\mathrm{NfM}+\mathrm{Y})$, as it has already been reported that a trace amount of fixed nitrogen is required for the isolation of most diazotrophs from the rhizosphere of rice (Gyaneshwar et al., 2001). The samples were incubated at $28{ }^{\circ} \mathrm{C}$ for $4-5$ days. Tubes showing a fine subsurface pellicle were transferred to fresh $\mathrm{NfM}+\mathrm{Y}$ for further incubation and observation of pellicle formation. Further purification was performed by repeatedly streaking the isolates on plates of $\mathrm{NfM}+\mathrm{Y}$ agar followed by tryptone soy agar (TSA; HiMedia) supplemented with $1.5 \% \mathrm{NaCl}(\mathrm{TSA}+\mathrm{NaCl})$. Both strains were maintained on TSA $+\mathrm{NaCl}$ at $4{ }^{\circ} \mathrm{C}$ or were stored frozen in tryptone soy broth (TSB; HiMedia) supplemented with $1.5 \% \mathrm{NaCl}(\mathrm{TSB}+\mathrm{NaCl})$ with $15 \%$ glycerol at $-80{ }^{\circ} \mathrm{C}$.

Genomic DNA was extracted from strains MSSRF $30^{\mathrm{T}}$ and MSSRF31 as described by Ausubel et al. (1987). The 16S rRNA gene was amplified and sequenced as described previously by Saha et al. (2005) and the recA, rpoA and pyrH genes were amplified and sequenced according to Thompson et al. (2005). The primer sequences that were used for amplification and sequencing for the 16S rRNA, recA, rpoA and pyrH genes are listed in Supplementary Table S1 (see IJSEM Online). The sequences of these genes were compared with the sequences available from GenBank using the BLASTN program (Altschul et al., 1990) and were aligned using CLUSTAL_X software (Thompson et al., 1997). Distances were calculated according to Kimura's twoparameter correction (Kimura, 1980). Phylogenetic trees were inferred using the neighbour-joining method (Saitou \& Nei, 1987). Bootstrap analysis was based on 1000 resamplings. The MEGA3 package (Kumar et al., 2004) was used for all analyses.

The partial 16S rRNA gene sequences comprising 1359 nucleotides were determined for strains $\mathrm{MSSRF}^{\mathrm{T}} 0^{\mathrm{T}}$ and MSSRF31. A comparison with the 16S rRNA gene sequences of all of the recognized members of the genus Vibrio held in GenBank indicated that both strains were phylogenetically related to members of this genus (Fig. 1). Strains MSSRF $30^{\mathrm{T}}$ and MSSRF31 were identical when the pairwise 16S rRNA gene sequence similarity was deter- mined. The gene sequence similarities between strain MSSRF $30^{\mathrm{T}}$ and $V$. fluvialis LMG $7894^{\mathrm{T}}$, V. furnissii LMG $7910^{\mathrm{T}}$ and $V$. tubiashii CIP $102760^{\mathrm{T}}$ were $96.8 \%$, $96.8 \%$ and $96.7 \%$, respectively, but were less than $96.7 \%$ when compared with other species of the genus Vibrio. Gene sequence similarity values of not more than $93.0 \%$ were found when strain MSSRF30 ${ }^{\mathrm{T}}$ was compared with other genera in the family Vibrionaceae. The node to which strains MSSRF30 ${ }^{\mathrm{T}}$ and MSSRF31 belonged was also supported in phylogenetic trees generated with the maximum-likelihood and maximum-parsimony algorithms (data not shown). These gene sequence similarity values are below the cut-off value of $97.0 \%$, the level normally judged sufficient to justify the proposal of a novel bacterial species (Stackebrandt \& Goebel, 1994).

Other housekeeping genes previously found to be useful in the differentiation of members of the genus Vibrio and related species (Thompson et al., 2004a, 2005; Kumar \& Nair, 2007) were also analysed. Analysis of the rpoA gene sequence also supported the phylogenetic position of strains MSSRF $30^{\mathrm{T}}$ and MSSRF31 within the genus Vibrio. The novel strains showed $100 \%$ rpoA gene sequence similarity with each other, $93.0 \%$ similarity with $V$. fluvialis LMG $7894^{\mathrm{T}}$ and $92.3 \%$ similarity with $V$. furnissii LMG $7910^{\mathrm{T}}$ (see Supplementary Fig. S1 in IJSEM Online). The remaining species of the genus Vibrio showed less than $92.3 \%$ similarity with the novel strains. This result was in agreement with the 16S rRNA gene sequence analysis and coincided with those obtained by other workers. This indicates that rpoA gene sequence analyses correlate well with those based on 16S rRNA gene sequences (Kumar \& Nair, 2007; Thompson et al., 2005) and that the rpoA gene evolves as slowly as the 16S rRNA gene (Zeigler, 2003).

The recA and $p y r H$ genes have also been proposed as an alternative marker for the family Vibrionaceae and their sequences seem to be more discriminatory than those of the $r p o A$ and $16 \mathrm{~S}$ rRNA genes for the genus Vibrio (Kumar \& Nair, 2007; Thompson et al., 2005). A pairwise analysis of the $r e c A$ sequences of strains MSSRF30 ${ }^{\mathrm{T}}$ and MSSRF31 revealed $100 \%$ sequence similarity between the two strains. Low levels of gene sequence similarity were found with several species from the genus Vibrio. For example, the analysis pointed to $87.3 \%$ gene sequence similarity with $V$. diazotrophicus LMG $7893^{\mathrm{T}}, 86.6 \%$ with $V$. rotiferianus LMG $21460^{\mathrm{T}}, 84.8 \%$ with $V$. furnissii LMG $7910^{\mathrm{T}}$ and $84.0 \%$ with $V$. fluvialis LMG $7894^{\mathrm{T}}$ (see Supplementary Fig. $\mathrm{S} 2$ in IJSEM Online). The pyrH gene sequence analysis also supported the phylogenetic position of strain MSSRF $30^{\mathrm{T}}$ within the genus Vibrio as this strain showed low levels of similarity, 83.6-86.6\%, with respect to all of the recognized species of the genus Vibrio. A phylogenetic tree showing this relationship is available as Supplementary Fig. S3 (available in IJSEM Online).

The low gene sequence similarity values found between the four genes for recognized species of the genus Vibrio and strains MSSRF $30^{\mathrm{T}}$ and MSSRF31 confirmed that the novel 


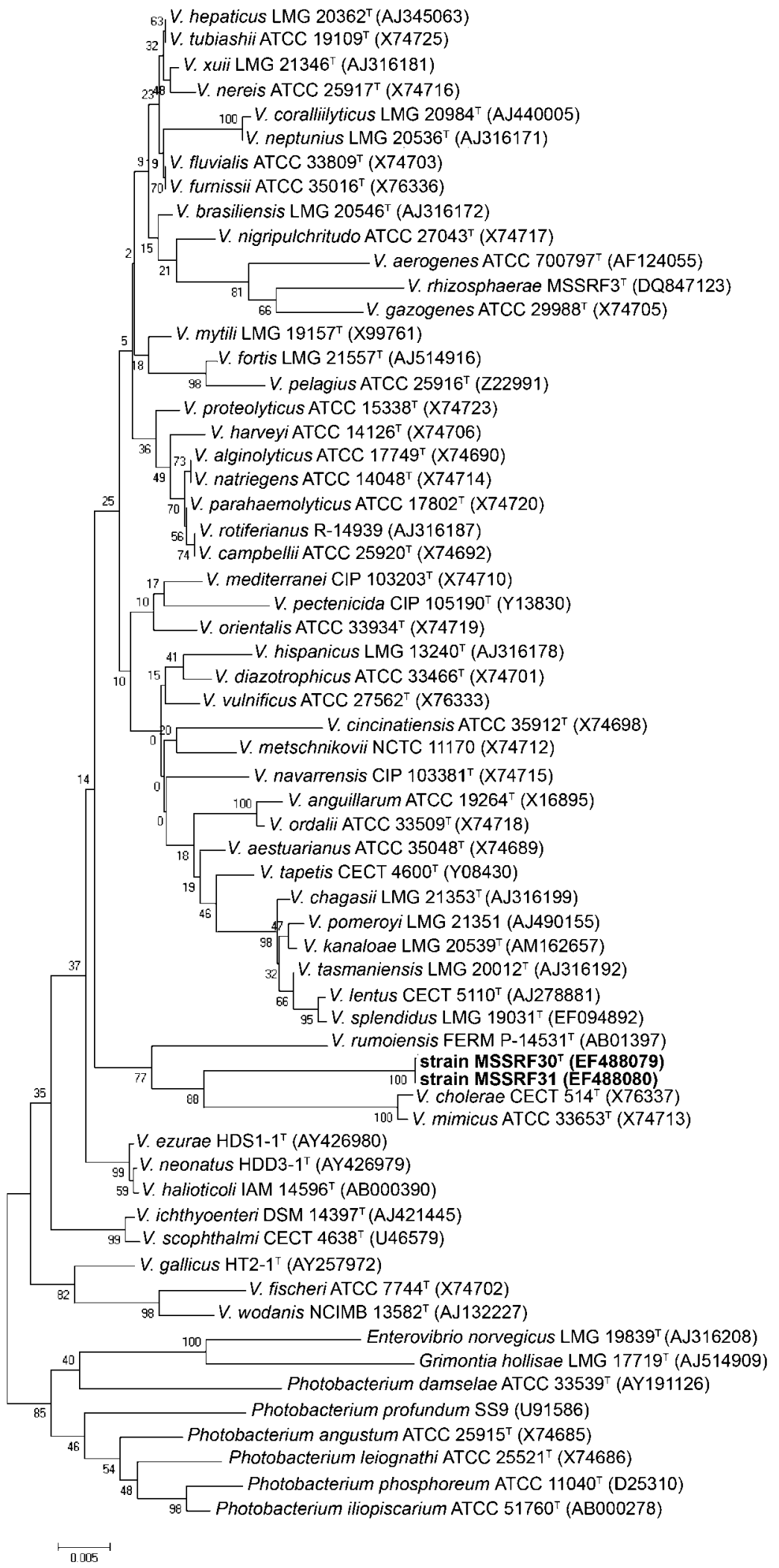

Fig. 1. Neighbour-joining phylogenetic tree based on partial 16S rRNA gene sequences of Vibrio porteresiae sp. nov. MSSRF $30^{\top}$ and other related organisms of the family Vibrionaceae. Bar, 0.005 substitutions per nucleotide position. strains did not belong to the currently recognized Vibrio species (Thompson et al., 2005). The position of isolates MSSRF30 $^{\mathrm{T}}$ and MSSRF31 varied between the trees constructed from the different genetic loci, suggesting that recombination/gene conversion events in the $r p o A, \operatorname{rec} A$ and $p y r H$ genes might have occurred among these Vibrio 
species (Thompson et al., 2005). These recombination events hampered the exact identification and positioning of isolates MSSRF $30^{\mathrm{T}}$ and MSSRF31 in the genus Vibrio. In order to overcome the effects of gene conversion and recombination, multigene phylogenetic trees were constructed for strains MSSRF30 ${ }^{T}$ and MSSRF31 using the four genes. The sequences of the pyrH (445 bp), recA (652 bp), rpoA (834 bp) and 16S rRNA genes (1272 bp) of 62 representative type strains (Thompson et al., 2005; Sawabe et al., 2007b), including strain MSSRF $30^{\mathrm{T}}$, of the family Vibrionaceae were retained and used to reconstruct a concatenated network tree based on SPLITSTREE version 4.6 (Huson \& Bryant, 2005). In the sPLITS decomposition analysis using nine gene loci, at least 14 distinctive clades were recognized for vibrios (Sawabe et al., 2007b). Even in the four-gene-concatenated network tree, the clade was likely to be retained. Strains MSSRF $30^{\mathrm{T}}$ and MSSRF31 occupied a distinct phylogenetic position, forming a long branching that was not clustered with $V$. cholerae, $V$. mimicus, $V$. furnissii, $V$. fluvialis and $V$. diazotrophicus or with any other recognized Vibrio species. Strains MSSRF30 ${ }^{\mathrm{T}}$ and MSSRF31 may belong to the $V$. cholerae clade (Fig. 2), as defined by Sawabe et al. (2007b), which is strong evidence to propose these two new isolates as a novel taxon in the genus Vibrio.

Repetitive extragenic palindromic PCR (Rep-PCR) fingerprinting using the $\mathrm{GTG}_{5}$ primer was performed as described previously (Ben-Haim et al., 2003) using $V$. cholerae IID6019, V. mimicus LMG 7896 ${ }^{\mathrm{T}}$, V. fluvialis LMG $7894^{\mathrm{T}}$ and $V$. furnissii LMG $7910^{\mathrm{T}}$ as references. The results showed that no similarity was observed between the fingerprints of strains MSSRF30 ${ }^{\mathrm{T}}$ and MSSRF31 and those of the reference strains (see Supplementary Fig. S4 available in IJSEM Online). Thus, the $\mathrm{GTG}_{5}$-generated PCR fingerprints were in agreement with the findings above and indicated that the two new isolates are members of a single novel species.

Fatty acid methyl ester (FAME) analysis for strain MSSRF30 ${ }^{\mathrm{T}}$ was performed at the Belgian Coordinated Collections of Micro-organisms Laboratorium voor Microbiologie (Universiteit Gent, Belgium) according to the recommendations of the commercial MIDI identification system (Microbial Identification System, Inc.). For

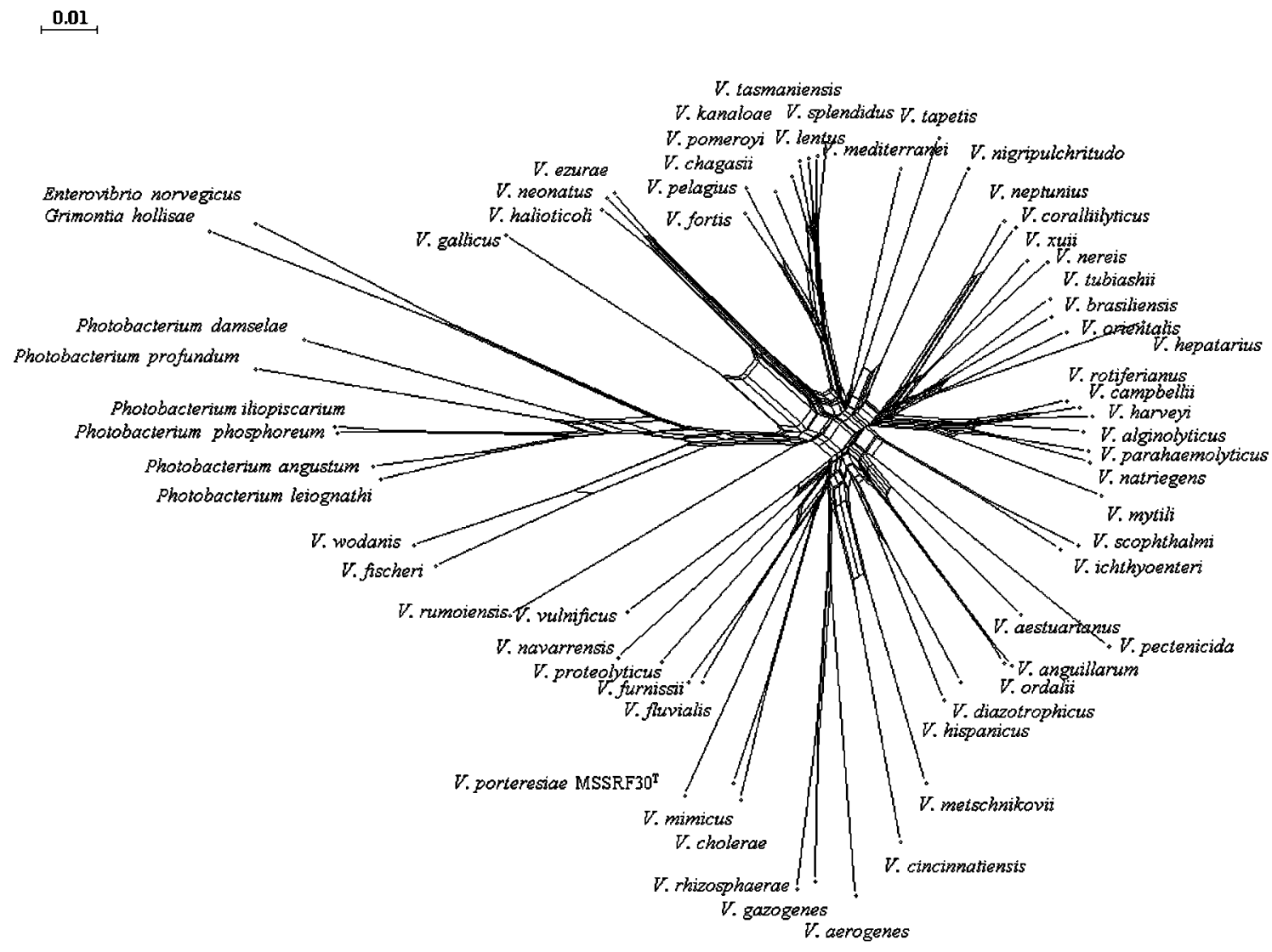

Fig. 2. Concatenated split network tree based on four gene loci. The $p y r H, r e c A, r p o A$ and $16 \mathrm{~S}$ rRNA gene sequences (3203 bp) from 62 taxa were concatenated and reconstructed by SPLITSTREE4 (version 4.6). Distances were corrected with the Jukes-Cantor correlation. Strain MSSRF31 had identical 16S rRNA and protein-coding gene sequences and clustered with strain MSSRF30 ${ }^{\top}$. Bar, 1 nucleotide substitution per 100 nucleotide positions. 
fatty acids analyses, strain MSSRF $30^{\mathrm{T}}$ was cultivated for $24 \mathrm{~h}$ at $28{ }^{\circ} \mathrm{C}$ on TSA medium supplemented with $1.5 \%$ $\mathrm{NaCl}$. The results of the analysis revealed that strain MSSRF $30^{\mathrm{T}}$ possessed the main chemotaxonomic features that are typical for the genus Vibrio (Bertone et al., 1996; Lambert et al., 1983). The predominant fatty acids (accounting for $>80 \%$ of the total cellular fatty acid content) were summed feature 3 (comprising $\mathrm{C}_{16: 1} \omega 7 c$ and/or $\mathrm{C}_{15: 0}$ iso 2-OH), $\mathrm{C}_{16: 0}, \mathrm{C}_{18: 1} \omega 7 c, \mathrm{C}_{14: 0}$ and $\mathrm{C}_{12: 0}$. The results of the FAME analyses are given in the species description.

DNA of strain MSSRF30 ${ }^{\mathrm{T}}$ was prepared according to the procedures of Marmur (1961), with minor modifications. The $\mathrm{G}+\mathrm{C}$ content of the DNA was determined by HPLC (Tamaoka \& Komagata, 1984) as a mean value of triplicate samples. The DNA G $+\mathrm{C}$ content was $44.4 \pm 3.1 \mathrm{~mol} \%$ for strain MSSRF $30^{\mathrm{T}}$, which was in good agreement with the values previously found for members of the genus Vibrio (Baumann et al., 1984).

Cells of strains MSSRF30 ${ }^{\mathrm{T}}$ and MSSRF31 were grown in $\mathrm{TSB}+\mathrm{NaCl}$ for $24 \mathrm{~h}$ and were examined for morphology and motility using a phase-contrast microscope. Classical phenotypic tests were performed as described previously (Baumann et al., 1984; Farmer \& Hickman-Brenner, 1992; Leifson, 1963). The ability of the cultures to utilize various carbon compounds as the sole carbon source was investigated by testing $0.5 \%$ carbon compound in a minimal base medium containing $2.0 \%(\mathrm{w} / \mathrm{v}) \mathrm{NaCl}$, $1.0 \%(\mathrm{w} / \mathrm{v}) \mathrm{K}_{2} \mathrm{HPO}_{4}, 0.45 \%(\mathrm{w} / \mathrm{v}) \mathrm{KH}_{2} \mathrm{PO}_{4}, 0.14 \%(\mathrm{w} / \mathrm{v})$ $\mathrm{CaCl}_{2}, 0.15 \%$ (w/v) $\mathrm{MgCl}_{2}, 0.075 \%$ (w/v) $\mathrm{KCl}, 0.1 \%$ $(\mathrm{w} / \mathrm{v})\left(\mathrm{NH}_{4}\right)_{2} \mathrm{SO}_{4}$ and $1.5 \%(\mathrm{w} / \mathrm{v})$ agar. The results were noted after 3 days of incubation at $28{ }^{\circ} \mathrm{C}$. Growth in different salt concentrations was monitored in tubes of $1 \%$ tryptone broth $\mathrm{pH} 7.5$ (with $\mathrm{NaCl}$ concentrations of 0 to $10 \%$ ) incubated for 7 days at $28{ }^{\circ} \mathrm{C}$ and growth in thiosulfate citrate bile salts medium (TCBS; from three manufacturers, Oxoid, Merck and Eiken) was monitored for 2 days of incubation at $28{ }^{\circ} \mathrm{C}$. V. fluvialis LMG $7894^{\mathrm{T}}$ and $V$. furnissii LMG $7910^{\mathrm{T}}$ were used as reference strains. The results showed that strains MSSRF30 ${ }^{\mathrm{T}}$ and MSSRF31 possessed the main phenotypic features characteristic for the genus Vibrio; they were straight to slightly curved rods, motile, facultatively anaerobic, Gram-negative, oxidase- and catalase-positive and their growth was stimulated by $\mathrm{NaCl}$. The phenotypic characteristics of strain MSSRF $30^{\mathrm{T}}$ are given in the species description below. Strains MSSRF30 $0^{\mathrm{T}}$ and MSSRF31 possessed some phenotypic characteristics that are quite uncommon among the vibrios, including production of gas from glucose, resistance to $\mathrm{O} / 129$ and no growth in TCBS. The species $V$. gazogenes, $V$. aerogenes, $V$. ruber, $V$. rhizosphaerae and $V$. furnissii are the only other Vibrio species that have been previously reported to produce gas from glucose (Shieh et al., 2000, 2003; Kumar \& Nair, 2007). However, $V$. gazogenes, $V$. ruber and $V$. rhizosphaerae produce red colonies on plate media. Moreover, these strains are negative for the oxidase reaction (Shieh et al., 2000, 2003; Kumar \& Nair, 2007). Colonies produced by strain MSSRF $30^{\mathrm{T}}$, on the other hand, were white and were positive for the oxidase reaction. The only species of the genus Vibrio previously reported to show no growth in TCBS is $V$. pectenicida (Lambert et al., 1998). In addition, strain MSSRF $30^{\mathrm{T}}$ could be differentiated from $V$. cholerae and $V$. mimicus on the basis of many biochemical and physiological properties such as no growth at $0 \% \mathrm{NaCl}$, no growth in TCBS, resistance to $\mathrm{O} / 129$, production of gas from glucose, positive utilization of D-xylose, cellobiose, lactose, salicin and L-rhamnose, and negative results in tests for nitrate reduction and amylase. Furthermore, the novel strain could be differentiated from all other Vibrio species by the following combination of properties: no growth in TCBS, negative in tests for arginine dihydrolase and ornithine decarboxylase, positive in tests for nitrogen fixation, production of gas from glucose and for the utilization of D-xylose and lactose. The novel strain gave a negative result in tests for nitrate reduction, was unable to utilize trehalose and was resistant to O/129. Differential features between the novel strains and closely related members of the genus Vibrio are presented in Table 1.

The acetylene reduction assay (ARA) was used to test the isolates grown on semi-solid $(\mathrm{NfM}+\mathrm{Y})$ medium for potential nitrogen fixation. The amount of ethylene produced was measured using $10 \%(\mathrm{v} / \mathrm{v})$ acetylene according to the method of Li \& MacRae (1992) using a Hewlett Packard 4890 GC equipped with a Poropack N column. Strains MSSRF30 ${ }^{\mathrm{T}}$ and MSSRF31 were able to reduce acetylene to ethylene and fixed $39.68 \pm 1.42$ and $38.2 \pm 2.0$ (nmoles of ethylene $\mathrm{ml}^{-1} \mathrm{~h}^{-1}$ ), respectively. The strains were subjected to a nifH-specific PCR amplification using the primers of Ueda et al. (1995) and the expected $390 \mathrm{bp}$ amplification product was observed in both isolates and negative results were observed with $V$. fluvialis LMG $7894^{\mathrm{T}}$ and $V$. furnissii LMG $7910^{\mathrm{T}}$ (Fig. 3). The amplified $390 \mathrm{bp}$ fragments of strains MSSRF30 ${ }^{\mathrm{T}}$ and MSSRF31 were sequenced and were found to show $100 \%$ sequence similarity. The $390 \mathrm{bp}$ fragment showed $83.0 \%$ sequence similarity with those of $V$. diazotrophicus and $V$. natriegens; however, similarities with other nifH sequences from the NCBI database were 76.0 to $90.0 \%$. Thus, the results of the ARA and the presence of the nifH gene confirmed the nitrogen-fixing ability of strains MSSRF $30^{\mathrm{T}}$ and MSSRF31.

To confirm the above results obtained from biochemical, genotyping and phylogenetic analyses, DNA-DNA hybridization was performed between strain MSSRF $30^{\mathrm{T}}$ and its phylogenetic closest relatives, $V$. cholerae IID6019, V. mimicus LMG $7896^{\mathrm{T}}$, V. fluvialis LMG $7894^{\mathrm{T}}$, V. furnissii LMG $7910^{\mathrm{T}}$ and $V$. diazotrophicus LMG $7893^{\mathrm{T}}$, in microdilution wells by using a fluorometric direct binding method (Ezaki et al., 1988, 1989) as described previously (Sawabe et al., 1998, 2004, 2007a). Genomic DNA of strain MSSRF $30^{\mathrm{T}}$ was labelled with photoprobe biotin (Vector Labxoratories). Strain MSSRF30 $30^{\mathrm{T}}$ exhibited low DNA-DNA relatedness with the phylogenetically related type strains of V. cholerae IID6019 (13\%), V. mimicus LMG $7896^{\mathrm{T}}$ (12\%), 
Table 1. Features useful for differentiating Vibrio porteresiae sp. nov. MSSRF30 ${ }^{\top}$ from closely related species of the genus Vibrio

Species: 1, Vibrio porteresiae sp. nov. ( $n=2) ; 2$, V. fluvialis (data from Macián et al., 2004); 3, V. furnissii (from Macián et al., 2004); 4, V. tubiashii (Alsina \& Blanch, 1994); 5, V. hepatarius (Thompson et al., 2003); 6, V. vulnificus (Baumann et al., 1984); 7, V. fortis (Thompson et al., 2003); 8, V. cholerae (Farmer \& Hickman-Brenner, 1992); 9, V. mimicus (Farmer \& Hickman-Brenner, 1992); 10, V. diazotrophicus (Farmer \& HickmanBrenner, 1992). +, Positive; -, negative; ND, no data; v, variable.

\begin{tabular}{|c|c|c|c|c|c|c|c|c|c|c|}
\hline Biochemical characteristic & 1 & 2 & 3 & 4 & 5 & 6 & 7 & 8 & 9 & 10 \\
\hline Voges-Proskauer & + & - & - & - & + & - & $\mathrm{V}$ & + & - & - \\
\hline Amylase & - & + & + & + & $\mathrm{ND}$ & + & ND & + & ND & + \\
\hline Caseinase & - & + & + & ND & ND & + & ND & + & + & ND \\
\hline $\mathrm{NaCl}$ required for growth & + & + & $\mathrm{V}$ & + & - & + & + & - & - & + \\
\hline \multicolumn{11}{|l|}{ Utilization of: } \\
\hline L-Arabinose & - & + & + & - & - & - & - & - & - & + \\
\hline Cellobiose & + & - & - & + & + & + & + & - & - & + \\
\hline Trehalose & - & + & + & + & + & + & + & + & + & + \\
\hline Lactose & + & - & - & $\mathrm{V}$ & - & $\mathrm{V}$ & - & - & - & + \\
\hline Rhamnose & + & - & - & - & - & - & - & - & - & - \\
\hline
\end{tabular}

V. fluvialis LMG $7894^{\mathrm{T}}$ (14\%), V. furnissii LMG $7910^{\mathrm{T}}$ $(13 \%)$ and V. diazotrophicus LMG $7893^{\mathrm{T}}(9.9 \%)$.

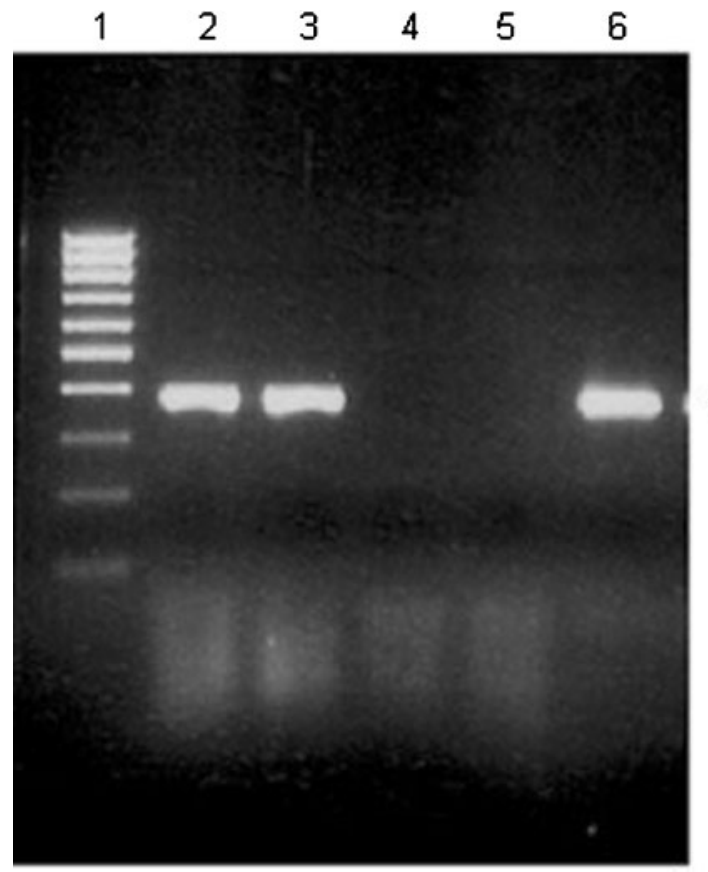

$390 \mathrm{bp}$

Fig. 3. PCR amplification of the nifH gene from two novel diazotrophs of the genus Vibrio. Lanes: 1, 100 bp marker; 2, MSSRF30'; 3 , MSSRF31; 4, V. fluvialis LMG $7894^{\top} ; 5$, V. furnissii LMG $7910^{\top} ; 6$, Swaminathania salitolerans $\mathrm{PA}^{\top} 1^{\top}$ (positive control).
Based on phenotypic, phylogenetic (multilocus sequence analysis using $16 \mathrm{~S}$ rRNA, recA, pyrH, rpoA and nifH genes), genotypic (genomic fingerprinting using the $\mathrm{GTG}_{5}$ primer), chemotaxonomic and DNA-DNA hybridization analyses presented here, it is concluded that strain MSSRF $30^{\mathrm{T}}$ should be classified as representing a novel species of the genus Vibrio. The name Vibrio porteresiae sp. nov. is proposed.

\section{Description of Vibrio porteresiae sp. nov.}

Vibrio porteresiae (por.te.re'si.ae. N.L. gen. fem. n. porteresiae of porteresia, because the organism was isolated from Porteresia coarctata, a wild relative of rice growing in mangroves).

Cells are Gram-negative, straight to slightly curved rods $(0.9 \times 1.0-2.0 \mu \mathrm{m})$ which occur singly or in pairs and are motile. Colonies on TSA supplemented with $1.5 \%(\mathrm{w} / \mathrm{v})$ $\mathrm{NaCl}$ are circular, smooth, and white with exopolysaccharide production within 2 days at $28{ }^{\circ} \mathrm{C}$. Swarming is not detected. Able to fix atmospheric nitrogen. Positive for oxidase and catalase. The DNA G $+\mathrm{C}$ content of the type strain is $44.4 \pm 3.1 \mathrm{~mol} \%$. Positive result in the VogesProskauer reaction and in tests for aesculin hydrolysis and citrate utilization. Negative result in tests for indole production, $\mathrm{ONPG}$ and $\mathrm{H}_{2} \mathrm{~S}$ production. Does not produce arginine dihydrolase, lysine decarboxylase, ornithine decarboxylase, caseinase or amylase. Negative for the reduction of nitrate to nitrite and no growth is observed in TCBS. Grows in the presence of $\mathrm{NaCl}$ concentrations of up to $5 \%(\mathrm{w} / \mathrm{v})$, but not at $8 \% \mathrm{NaCl}$. Optimum growth occurs in the presence of $1-2 \%(\mathrm{w} / \mathrm{v}) \mathrm{NaCl}$ at $28{ }^{\circ} \mathrm{C}$. No 
growth is observed in $0 \% \mathrm{NaCl}$. Growth occurs at 20 $37{ }^{\circ} \mathrm{C}$ (optimal growth occurs at $28{ }^{\circ} \mathrm{C}$ ), but no growth occurs at 4 or $45{ }^{\circ} \mathrm{C}$, and at $\mathrm{pH}$ 5.5-9.0 (optimal growth occurs at $\mathrm{pH} 7$ ). Resistant to the vibriostatic agent $\mathrm{O} / 129$ (10 or $150 \mu \mathrm{g}$ per disc). Facultative anaerobe capable of both aerobic and anaerobic fermentative growth. Acid and gas are produced from fermentation of glucose. Other carbohydrates such as lactose, maltose, fructose, glucose, cellobiose, galactose, rhamnose, sucrose, xylose, mannitol and salicin are also fermented. Trehalose, dulcitol, raffinose, melibiose, sorbose, melezitose, inulin, glycerol, sorbitol, adonitol and inositol are not fermented. Grows in a mineral medium containing glucose and $\mathrm{NH}_{4} \mathrm{Cl}$. Utilizes cellobiose, lactose, sucrose, mannitol, salicin, rhamnose, xylose, fructose, glucose, maltose, mannitol, L-serine, and L-proline as sole carbon sources. Utilization of melibiose is weak. Does not use inulin, trehalose, inositol, dulcitol, arabinose, raffinose, sorbitol, mannose, L-alanine, Lcholine, L-ornithine, L-arginine, L-lysine, L-valine, Lmethionine or L-threonine as carbon sources. The most abundant fatty acids are summed feature $3(27.53 \%$; comprising $\mathrm{C}_{16: 1} \omega 7 c$ and/or $\mathrm{C}_{15: 0}$ iso $\left.2-\mathrm{OH}\right), \mathrm{C}_{16: 0}$ $(18.75 \%), \mathrm{C}_{18: 1} \omega 7 c \quad(19.20 \%), \mathrm{C}_{14: 0} \quad(8.15 \%), \mathrm{C}_{12: 0}$ $(6.84 \%)$, summed feature 2 (6.81\%; comprising an unidentified fatty acid with an equivalent chain-length of 10.928 and/or $\mathrm{C}_{12: 0}$ ALDE, $\mathrm{C}_{16: 1}$ iso I and/or $\mathrm{C}_{14: 0} 3-\mathrm{OH}$ ) and $\mathrm{C}_{12: 0} 3-\mathrm{OH}(6.40 \%)$. The following fatty acids are detected in small amounts; $\mathrm{C}_{10: 0}(0.08 \%), \mathrm{C}_{10: 0} 3-\mathrm{OH}$ $(0.49 \%), \mathrm{C}_{11: 0} 3-\mathrm{OH}(0.38 \%), \mathrm{C}_{13: 0}(0.25 \%), \mathrm{C}_{12: 0}$ $2-\mathrm{OH}(0.22 \%), \mathrm{C}_{12: 1} 3-\mathrm{OH}(0.25 \%)$, summed feature 1 (0.64\%; comprising $\mathrm{C}_{13: 0} 3-\mathrm{OH}$ and/or $\mathrm{C}_{15: 1}$ iso $\mathrm{I} / \mathrm{H}$ ), $\mathrm{C}_{15: 1} \omega 8 c(0.26 \%), \mathrm{Cl}_{6: 1} \omega 7 c$ alcohol $(0.26 \%), \mathrm{C}_{16: 1} \omega 5 c$ $(0.24 \%), \quad \mathrm{C}_{17: 1} \omega 8 c \quad(0.58 \%), \mathrm{C}_{17: 0} \quad(0.36 \%), \quad \mathrm{C}_{18: 0}$ $(0.58 \%), 11$ methyl $\mathrm{C}_{18: 1} \omega 7 c(0.82 \%)$ and an unidentified fatty acid with an equivalent chain-length of 12.484 $(0.94 \%)$.

The type strain, MSSRF30 ${ }^{\mathrm{T}} \quad\left(=\mathrm{LMG} \quad 24061^{\mathrm{T}}=\mathrm{DSM}\right.$ $\left.19223^{\mathrm{T}}\right)$, was isolated from Porteresia coarctata, a wild relative of rice growing in mangroves.

\section{Acknowledgements}

This work was carried out with financial support from the Department of Biotechnology, Government of India. T. S. is grateful for the support from a grant from the Institute of Fermentation, Osaka, Japan.

\section{References}

Alsina, M. \& Blanch, A. R. (1994). A set of keys for biochemical identification of environmental Vibrio species. J Appl Bacteriol 76, 79-85.

Altschul, S. F., Gish, W., Miller, W., Myers, E. W. \& Lipman, D. J. (1990). Basic local alignment search tool. J Mol Biol 215, 403-410.

Ausubel, F. M., Brent, R., Kingston, R. E., Moore, D. D., Seidman, J. G., Smith, J. A. \& Struhl, K. (1987). Current Protocols in Molecular Biology. New York: Wiley.
Baumann, P., Furniss, A. L. \& Lee, J. V. (1984). Genus I. Vibrio Pacini 1854, 411. In Bergey's Manual of Systematic Bacteriology, vol. 1, pp. 518-538. Edited by N. R. Krieg \& J. G. Holt. Baltimore: Williams \& Wilkins.

Ben-Haim, Y., Thompson, F. L., Thompson, C. C., Cnockaert, M. C., Hoste, B., Swings, J. \& Rosenberg, E. (2003). Vibrio coralliilyticus sp. nov., a temperature-dependent pathogen of the coral Pocillopora damicornis. Int J Syst Evol Microbiol 53, 309-315.

Bertone, S., Giacomini, M., Ruggiero, C., Piccarolo, C. \& Calegarin, L. (1996). Automated systems for identification of heterotrophic marine bacteria on the basis of their fatty acid composition. Appl Environ Microbiol 62, 2122-2132.

Ezaki, T., Hashimoto, Y., Takeuchi, N., Yamamoto, H., Liu, S.-L., Miura, H., Matsui, K. \& Yabuuchi, E. (1988). Simple genetic method to identify viridans group streptococci by colorimetric dot hybridization and fluorometric hybridization in microdilution wells. J Clin Microbiol 26, 1708-1713.

Ezaki, T., Hashimoto, Y. \& Yabuuchi, E. (1989). Fluorometric deoxyribonucleic acid-deoxyribonucleic acid hybridization in microdilution wells as an alternative to membrane filter hybridization in which radioisotopes are used to determine genetic relatedness among bacterial strains. Int J Syst Bacteriol 39, 224-229.

Farmer, J. J., III \& Hickman-Brenner, F. W. (1992). The genera Vibrio and Photobacterium. In The Prokaryotes. A Handbook on the Biology of Bacteria: Ecophysiology, Isolation, Identification, Applications, 2nd edn, pp. 2952-3011. Edited by A. Balows, H. G. Trüper, M. Dworkin, W. Harder \& K. H. Schleifer. New York: Springer.

Guerinot, M. L., West, P. A., Lee, J. V. \& Colwell, R. R. (1982). Vibrio diazotrophicus sp. nov., a marine nitrogen-fixing bacterium. Int J Syst Bacteriol 32, 350-357.

Gyaneshwar, P., James, E. K., Mathan, N., Reddy, P. M., ReinholdHurek, B. \& Ladha, J. K. (2001). Endophytic colonization of rice by a diazotrophic strain of Serratia marcescens. J Bacteriol 183, 2634-2645.

Holguin, G., Guzman, M. A. \& Bashan, Y. (1992). Two new nitrogenfixing bacteria from the rhizosphere of mangrove trees: their isolation, identification and in vitro interaction with rhizosphere Staphylococcus sp. FEMS Microbiol Ecol 101, 201-216.

Huson, D. H. \& Bryant, D. (2005). Application of phylogenetic networks in evolutionary studies. Mol Biol Evol 23, 254-267.

Kimura, M. (1980). A simple method for estimating evolutionary rates of base substitutions through comparative studies of nucleotide sequences. J Mol Evol 16, 111-120.

Kumar, N. R. \& Nair, S. (2007). Vibrio rhizosphaerae sp. nov., a redpigmented bacterium that antagonizes phytopathogenic bacteria. Int $J$ Syst Evol Microbiol 57, 2241-2246.

Kumar, S., Tamura, K. \& Nei, M. (2004). MEGA3: integrated software for molecular evolutionary genetics analysis and sequence alignment. Brief Bioinform 5, 150-163.

Lambert, M. A., Hickman-Brenner, F. W., Farmer, J. J., III \& Moss, C. W. (1983). Differentiation of Vibrionaceae species by their cellular fatty acid composition. Int J Syst Bacteriol 33, 777-792.

Lambert, C., Nicolas, J. L., Cilia, V. \& Corre, S. (1998). Vibrio pectenicida sp. nov., a pathogen of scallop (Pecten maximus) larvae. Int J Syst Bacteriol 48, 481-487.

Leifson, E. (1963). Determination of carbohydrate metabolism of marine bacteria. J Bacteriol 85, 1183-1184.

Li, R. \& MacRae, I. C. (1992). Specific identification and enumeration of Acetobacter diazotrophicus in sugarcane. Soil Biol Biochem 24, 413-419.

Macián, M. C., Garay, E., Grimont, A. D. \& Pujalte, M. J. (2004). Vibrio ponticus sp. nov., a neighbour of $V$. fluvialis $-V$. furnissii clade, isolated 
from gilthead sea bream, mussels and seawater. Syst Appl Microbiol 27, 535-540.

Marmur, J. (1961). A procedure for the isolation of deoxyribonucleic acid from microorganisms. J Mol Biol 3, 208-218.

Saha, P., Krishnamurthi, S., Mayilraj, S., Prasad, G. S., Bora, T. C. \& Chakrabarti, T. (2005). Aquimonas voraii gen. nov., sp. nov., a novel gammaproteobacterium isolated from a warm spring of Assam, India. Int J Syst Evol Microbiol 55, 1491-1495.

Saitou, N. \& Nei, M. (1987). The neighbor-joining method: a new method for reconstructing phylogenetic trees. Mol Biol Evol 4, 406-425.

Sawabe, T., Sugimura, I., Ohtsuka, M., Nakano, K., Tajima, K., Ezura, Y. \& Christen, R. (1998). Vibrio halioticoli sp. nov., a non-motile alginolytic marine bacterium isolated from the gut of the abalone Haliotis discus hannai. Int J Syst Bacteriol 48, 573-580.

Sawabe, T., Hayashi, K., Moriwaki, J., Thompson, F. L., Swings, J., Potin, P., Christen, R. \& Ezura, Y. (2004). Vibrio gallicus sp. nov., isolated from the gut of the French abalone Haliotis tuberculata. Int $J$ Syst Evol Microbiol 54, 843-846.

Sawabe, T., Fujimura, Y., Niwa, K. \& Aono, H. (2007a). Vibrio comitans sp. nov., Vibrio rarus sp. nov. and Vibrio inusitatus sp. nov., from the gut of the abalones Haliotis discus discus, H. gigantea, $H$. madaka and H. rufescens. Int J Syst Evol Microbiol 57, 916-922.

Sawabe, T., Kita-Tsukamoto, K. \& Thompson, F. L. (2007b). Inferring the evolutionary history of vibrios by means of multilocus sequence analysis. J Bacteriol 189, 7932-7936.

Shieh, W. Y., Chen, A.-L. \& Chiu, H.-H. (2000). Vibrio aerogenes sp. nov., a facultatively anaerobic marine bacterium that ferments glucose with gas production. Int J Syst Evol Microbiol 50, 321-329.

Shieh, W. Y., Chen, Y.-W., Chaw, S.-M. \& Chiu, H.-H. (2003). Vibrio ruber sp. nov., a red, facultatively anaerobic, marine bacterium isolated from sea water. Int J Syst Evol Microbiol 53, 479-484.
Stackebrandt, E. \& Goebel, B. M. (1994). Taxonomic note: a place for DNA-DNA reassociation and 16S rRNA sequence analysis in the present species definition in bacteriology. Int J Syst Bacteriol 44, 846-849.

Tamaoka, J. \& Komagata, K. (1984). Determination of DNA base composition by reversed-phase high-performance liquid chromatography. FEMS Microbiol Lett 25, 125-128.

Thompson, J. D., Gibson, T. J., Plewniak, F., Jeanmougin, F. \& Higgins, D. G. (1997). The CLUSTAL_X windows interface: flexible strategies for multiple sequence alignment aided by quality analysis tools. Nucleic Acids Res 25, 4876-4882.

Thompson, F. L., Thompson, C. C., Hoste, B., Vandemeulebroecke, K., Gullian, M. \& Swings, J. (2003). Vibrio fortis sp. nov., and Vibrio hepatarius sp. nov., isolated from aquatic animals and the marine environment. Int J Syst Evol Microbiol 53, 1495-1501.

Thompson, F. L., lida, T. \& Swings, J. (2004a). Biodiversity of vibrios. Microbiol Mol Biol Rev 68, 403-431.

Thompson, J. R., Randa, M. A., Marcelino, L. A., Tomita-Mitchell, A., Lim, E. \& Polz, M. F. (2004b). Diversity and dynamics of a north Atlantic coastal Vibrio community. Appl Environ Microbiol 70, 41034110.

Thompson, F. L., Gevers, D., Thompson, C. C., Dawyndt, P., Naser, S., Hoste, B., Munn, C. B. \& Swings, J. (2005). Phylogeny and molecular identification of vibrios on the basis of multilocus sequence analysis. Appl Environ Microbiol 71, 5107-5115.

Ueda, T., Suga, Y., Yahiro, N. \& Matsuguchi, T. (1995). Remarkable $\mathrm{N}_{2}$-fixing bacterial diversity detected in rice roots by molecular evolutionary analysis of nifH gene sequences. J Bacteriol 177, 1414-1417.

Urdaci, M. C., Stal, L. J. \& Marchand, M. (1988). Occurrence of nitrogen fixation among Vibrio spp. Arch Microbiol 150, 224-229.

Zeigler, D. R. (2003). Gene sequences useful for predicting relatedness of whole genomes in bacteria. Int J Syst Evol Microbiol 53, 1893-1900. 